\title{
Kristne palestinere på Vestbredden
}

EN STILLE FORDRIVELSE

Det foregår et stille drama i de palestinske områdene. Områdets kristne innbyggere reiser ut i en alarmerende fart og minker i antall for hvert år. Situasjonen er spesielt dramatisk i Betlehem. Dette har tradisjonelt vært en kristen by, men i dag utgjør de kristne rundt 25 prosent av byens befolkning.

Bård Kårtveit er s tipendiat i sosialantropologi ved Universitetet i Bergen/CMI med fokus på migrasjon og identitetshåndtering blant kristne palestinere. Tidligere skrevet hovedoppgaven "In the us I'm an Arab Terrorist, here I'm an American Punk!" om returmigrasjon fra USA til Vestbredden. 
TEKST: Bård Kårtveit

UTVANDRINGEN HAR foregått over lang tid, men har økt sterkt de siste seks årene. Jeg vil i denne artikkelen belyse hvordan en strukturell utarming av de palestinske områdene, kombinert med klassemessige forhold blant palestinerne, bidrar til en omfattende utvandring blant de kristne i området. ${ }^{\text {. }}$

De kristne palestinerne utgjør en svært liten, men ressurssterk gruppe i de okkuperte områdene. Gjennom vestlige kirker og misjonsskoler har de hatt tilgang på god utdanning og internasjonale kontakter, og de har lenge utgjort en handelsmessig og intellektuell elite i området. De har vært aktive i palestinsk politikk, kultur og næringsliv, og de har vært ledende i utformingen av en palestinsk nasjonal identitet. $^{2}$ De teller nå omkring $42000 \mathrm{i}$ Gaza og på Vestbredden inkludert
Jerusalem, og de forlater området i et urovekkende tempo. Siden 2000 har det reist ut rundt 800-900 personer per år. Kombinert med lave fødselstall gir dette svært mørke fremtidsutsikter. ${ }^{3}$ Etter to tusen års tilstedeværelse fryktes det at de palestinske områdene kan være nesten tomt for kristne innbyggere i løpet av noen tiår.

Bethlehem og nabobyene Beit Jala og Beit Sahour, også kalt "det kristne triangel”, utgjør et kjerneområde for kristne palestinere, og de knytter stor stolthet til områdets bibelske historie. Det bor både kristne og muslimer i disse byene, og relasjonene dem imellom er stort sett gode. Den kristne befolkningen utgjør til sammen 23000 i området. De er fordelt mellom til sammen I4 ulike kirkesamfunn, hvorav rundt halvparten tilhører den greskortodokse og rundt 30 prosent tilhører den romersk-katolske kirken.

\section{Utvandring fra Betlehemsområdet}

Betlehemsområdet har en lang tradisjon for utvandring. Gjennom hele i8oo-tallet reiste små grupper av unge palestinske menn til den vestlige delen av verden, motivert av drømmen om et rikt og fritt liv, helst i Sør- eller Nord-Amerika. Palestina var i denne perioden underlagt Det ottomanske riket, som fra midten av I80otallet var preget av stor indre uro og økonomiske nedgangstider. Utvandring fra riket var formelt ulovlig frem til ı896, noe som forklarer hvorfor man fikk den første store bølgen av utvandring fra slutten av I80o-tallet frem til omkring I920, en bølge som ble ledet an av kristne palestinere. Dette var ikke spesielt for Palestina. Også i Syria og i andre deler av Det ottomanske riket fant det sted en omfattende utvan- 
dring. Her, som i Palestina, la et høyt utdanningsnivå og vestlige kontakter til rette for at utvandringen ble spesielt stor blant kristne grupperinger. ${ }^{4}$ Et annet forhold som hadde stor betydning var innrullering i den ottomanske hæren.

De kristne palestinerne utgjør en liten, men svoert ressurssterk gruppe $i$ de okkuperte områdene.

Frem til begynnelsen av I900-tallet hadde kristne og jøder vært fritatt fra å delta i hæren. ${ }^{5}$ Fra og med I9o9 ble de derimot innrullert i hæren på linje med alle andre, og dette var noe mange motsatte seg. Frem mot og under første verdenskrig valgte derfor et stort antall kristne palestinere å rømme landet for å unngå tvangsinnrullering $\mathrm{i}$ de ottomanske styrkene. ${ }^{6}$ I denne første bølgen valgte mange å reise til LatinAmerika, hvor man ennå i dag finner store palestinske nettverk. ${ }^{7}$ Det største miljøet av diasporapalestinere finner man i Chile, hvor det antas å være mer enn 90000 palestinere med opphav i Betlehemsområdet. $^{8}$

Gjennom hele I9oo-tallet har palestinere reist ut som følge av blant annet krig, statlig undertrykkelse og økonomisk utarming. Utvandringens omfang har variert med konfliktnivået i området. I perioden I92I-I947, mens Palestina var underlagt britisk mandatstyre, var det relativt få som reiste ut, men den konfliktdrevne utvandringen økte sterkt med opprettelsen av staten Israel, og utdrivningen av palestinere fra de områdene som ble underlagt den nye staten. ${ }^{9}$ Vestbredden og
Gaza ble de da underlagt jordansk og egyptisk styre. Etter seksdagerskrigen i I967 ble Vestbredden og Gaza okkupert av Israel, og dette bidro naturlig nok til en dramatisk økning av utvandring fra området. Kristne palestinere dro stort sett til Sør- og NordAmerika, mens muslimske utvandrere ofte dro til Gulfstatene eller andre deler av Midtøsten. I kjølvannet av Oslo-avtalen i I993 vendte mange palestinere tilbake til de okkuperte områdene. Mange håpet $\mathrm{da}$ på en snarlig fredsløsning med Israel, og ville satse på en fredelig fremtid i det som skulle bli en egen palestinsk stat. Denne drømmen fikk en knekk da fredsprosessen brøt sammen og den andre intifadaen brøt ut i 2000. Siden den gang har den økonomiske situasjonen i området blitt stadig verre, og et økende antall familier har forlatt eller prøvd å forlate landet. Spesielt Betlehemsområdet har vært rammet av utvandring siden 2000 .

Den kristne utvandringen har vært gjenstand for mye internasjonal oppmerksomhet de siste årene. En forklaring som ofte går igjen $\mathrm{i}$ internasjonale medier er at kristne palestinere blir undertrykt og diskriminert av muslimske palestinere, og at dette er hovedgrunnen til at de reiser ut. Dette samsvarer godt med israelske interesser og forsøk på å fremstille Midtøstenkonflikten som en kamp mellom jøder og fundamentalistiske muslimer. Det stemmer derimot dårlig overens med hvordan kristne palestinere selv beskriver sin situasjon i området. Med en økende polarisering mellom Vesten og den muslimske verden, og med voksende støtte til islamske bevegelser i hele regionen, så er mange kristne palestinere bekymret for den videre politiske utviklingen også i Palestina. Denne uroen er likevel underordnet 
bekymringer knyttet til Israels okkupasjon og dens betydning for økonomien på Vestbredden. Ifølge en undersøkelse utført av forskere ved Universitetet i Betlehem, oppgir nesten ni av ti kristne palestinere økonomisk nød og politisk ufrihet som de viktigste grunnene til at folk reiser ut. ${ }^{\text {Io }}$ En omfattende utvandring finner sted blant både kristne og muslimske palestinere, og ifølge dem selv må dette ses i sammenheng med den israelske okkupasjonen og dens virkninger på samfunnet de lever i. Situasjonen i Betlehem er godt egnet til å belyse dette.

\section{En lammende okkupasjon}

Israel kontrollerer de palestinske områdene gjennom en kombinasjon av militære og strukturelle virkemidler. Den militære okkupasjonen omfatter blant annet bombing av militante mål og målrettede drap og arrestasjoner av palestinere tilknyttet militante motstandsgrupper. Den strukturelle okkupasjonen består av en rekke virkemidler som kan lamme økonomisk virksomhet og viktige samfunnsmessige funksjoner blant palestinerne. Betlehemsområdet regnes som ett av de fredeligste på Vestbredden, og er i mindre grad enn andre områder rammet av rent militær maktbruk. Når det gjelder den strukturelle okkupasjonen derimot, så er Betlehem rammet svært hardt. Siden september 2000 har Betlehem vært lammet av en vedvarende økonomisk krise. Ifølge borgermesteren i Betlehem sliter byen med en arbeidsledighet på over 50 prosent, og 60 prosent av befolkningen lever på under to dollar om dagen. Denne krisen har blitt drevet frem av en rekke strukturelle tiltak fra israelsk hold. Dette inkluderer en økonomisk isolering av Betlehem fra
Jerusalem, ekskludering av palestinske arbeidere fra Israel og bygging av den israelske muren på palestinsk jord.

\section{Økonomisk isolering av Betlehem}

Etter at den siste intifadaen brøt ut i 2000 , har Bethlehem blitt effektivt atskilt fra Jerusalem, først med sperring av veier mellom byene og senere med bygging av separasjonsmuren. Betlehem ligger bare åtte kilometer sør for Jerusalem og har lenge vært økonomisk avhengig av den nære forbindelsen til byen. Siden høsten 2000 har hovedveien til Jerusalem vært stengt av israelske myndigheter. Betlehems palestinere har siden da vært nektet innreise til Jerusalem, og det har blitt langt mer besværlig også for utlendinger å reise mellom byene.

Dette har vært en katastrofe for Betlehem, hvor nesten all økonomisk virksomhet har vært knyttet til turisme. I perioden 2000-2004 gikk turismen ned 85 prosent, og tusenvis av palestinere mistet sine jobber tilknyttet næringen. ${ }^{\text {II }}$ Hoteller og suvenirbutikker står tomme, statsautoriserte guider går uten arbeid, og oliventreutskjærere i Beit Sahour - et håndverk landsbyen lenge har vært kjent for - lager detaljrike figurer som stues vekk i lagerrom istedenfor å selges til turister.

Amer er en av rundt 400 statsautoriserte turistguider i Betlehem. Han er i utgangspunktet ingeniør, man da han slet med å finne arbeid valgte han i I999 å utdanne seg til å bli turistguide i regi av det palestinske turistdepartementet. Utdanningen tok to år, og måtte finansieres ved at han tok et lån på 20000 dollar. I I999 var turismen i vekst, og dette virket som et trygt og sikkert yrkesvalg. Da han var ferdig utdannet, to år senere, var intifadaen i 
gang, og turistene hadde sluttet å komme til Betlehem. Etter fem år med svært lite turisme er det bare 80 som fortsatt jobber som guider - i mangel på annet arbeid. Han har en bror som bor i New Jersey, og som prøver å hjelpe han med å få visum til USA for å følge etter. I mellomtiden sitter han utenfor Fødselskirken i Betlehem, og prøver å leve på de turistene som dukker opp.

\section{Utestengning av palestinske arbeidere}

Siden I970-tallet har også tusenvis av palestinere forsørget sine familier ved å arbeide inne i Israel. Fra og med 200 ble palestinere fra Vestbredden nektet innreise til Israel, og flere tusen palestinere som har utdannet seg nettopp for det israelske arbeidsmarkedet, stod da uten arbeid. En av dem var Marwan, en kristen palestiner fra Betlehem. I I 982 reiste han til Wien for å studere, og fire år senere vendte han hjem som nyutdannet elektroingeniør. Han fikk raskt arbeid i Jerusalem, og etter noen år startet han sitt eget firma hvor han hadde fire andre ingeniører under seg. Underveis ble han gift med en jente fra en nabolandsby, og de fikk fire døtre sammen.

Kristne palestinere dro ofte til Nordog Sør-Amerika, mens muslimske dro til andre steder i Midtøsten.

Firmaet i Jerusalem gikk veldig bra, og Marwans familie hadde en svært romslig økonomi. Dette endrer seg brått i januar 200I, noen måneder inne $\mathrm{i}$ den andre intifadaen. Når Marwan ble nektet innreise til Israel, ble han arbeidsledig over natten og måtte legge ned firmaet sitt. Siden $200 \mathrm{I}$ har han levd på sporadiske småjobber $\mathrm{i}$ Betlehem og vært arbeidsledig i lange perioder. Han har vært ute av stand til å forsørge familien sin alene og har vært avhengig av å motta økonomisk støtte fra slektninger bosatt i usa. Dette har vært tungt å godta for en mann som tidligere drev sitt eget firma. Samtidig har han opplevd at stadig flere slektninger og nære venner velger å forlate landet, og en søster bosatt i usA ønsker å hjelpe Marwan og familien hans til statene. Selv ønsker han fortsatt å bli boende i Palestina og håper at det skal være en fremtid her også for døtrene hans. Ikke alle deler Marwans standhaftighet her.

\section{Byggingen av muren}

Et annet forhold som har preget Betlehem de siste årene er byggingen av separasjonsmuren gjennom området. Siden begynnelsen av I970-årene har Israel konfiskert store mengder palestinsk jord, først for å bygge bosetninger og bosetningsveier rundt Betlehem, og siden 2002 for å bygge separasjonsmuren rundt byen. Dette har så langt gått hardest utover den nordlige delen av Betlehem, hvor muren har blitt bygget tvers igjennom det som tidligere var Betlehems travleste handlegater. Byggingen av muren har i løpet av få år forandret dette området til et spøkelsesstrøk. Mellom 2002 og 2004 ble 72 av 80 forretninger lagt ned. ${ }^{\mathrm{r2}}$ De som har hatt råd til det har forlatt området og etterlatt tomme hus og butikker. Claire tilhører en av få familier som ikke kom seg bort. Hun og hennes mann hadde hver sin butikk i familiens hus og gjorde det svært godt med kunder både fra Betlehem og fra Jerusalem på israelsk side. Da veien mellom byene ble 
stengt, forsvant de fleste kundene, og Claire og hennes mann måtte legge ned butikkene sine. I 2003 ble muren bygget gjennom nabolaget, og Claire opplevde at naboene deres gradvis forlot området. I 2005 ble det bygget ett tilbygg av muren rundt familiens hus, og huset er nå tett omsluttet av muren. Claire og familien har nå gitt opp, og ønsker å forlate området, men de har verken penger eller et nytt sted å flytte til, og det er bortimot umulig å selge et hus som har utsikt mot muren fra alle husets sider.

Murens virkning i det nordlige Betlehem gir bleke utsikter for nabobyen Beit Jala. Her har 60 prosent av jorden blitt konfiskert av Israel, og muren vil bli bygget tett rundt landsbyen. De landområdene som eies av kristne palestinere, har vært spesielt hardt rammet av landkonfiskering og byggingen av muren. ${ }^{\mathrm{i} 3}$ Med dagens planer vil separasjonsmuren bygges $i$ en ring rundt Betlehem og nabobyene Beit Jala og Beit Sahour, og all bevegelse inn og ut av dette området, enten man vil sør- eller nordover på Vestbredden eller inn til Israel, ville være regulert av israelske kontrollposter.

\section{Oppdeling av Vestbredden}

Disse kontrollpostene inngår også i en annen israelsk strategi: oppdelingen av Vestbredden i tre atskilte regioner. I løpet av få år har israelske myndigheter delt Vestbredden inn i en nordlig region, en midt region og en sørlig region. Med et økende antall kontrollposter som skaper lange køer og uforutsigbar stenging av kjørbare veier, har man på kort tid gjort det mye vanskeligere å reise mellom ulike deler av Vestbredden. Palestinere må ha tillatelse fra israelske myndigheter for å kjøre egen bil utenfor sine hjembyer, og folk opplever å være fanget innefor en liten del av Vestbredden. Ramallah som er det politiske og kommersielle sentrum på Vestbredden, var bare en tjue minutters kjøretur fra Betlehem inntil for få år siden, og folk som jobbet i Ramallah kunne pendle fra Betlehem daglig. I dag er dette blitt en umulighet, og folk fra Betlehem som jobber i Ramallah eller andre deler av Vestbredden, er blitt tvunget til å flytte dit. På sikt kan denne oppdelingen føre til en utvikling av tre separate samfunn på Vestbredden som har stadig mindre kontakt med hverandre.

\section{Deportering av hjemvendte palestinere}

I 2006 innførte Israel en ny grensepolitikk som har fått dramatiske konsekvenser for mange palestinere. Folk som har flyttet hjem til Vestbredden etter å ha bodd i utlandet i noen år, og som har utenlandske pass, blir nå deportert og nektet innreise til de okkuperte områdene igjen. Gjennom flere tiår har tusenvis av palestinere reist til andre deler av verden for å studere eller jobbe i noen år. Folk som forlot landet mellom I967 og I994 mistet sitt palestinske statsborgerskap og retten til å vende tilbake dersom de ble i utlandet i mer enn ett år av gangen.

De fleste endte opp med å få statsborgerskap i det land de studerte eller arbeidet $i$, men mange vendte likevel hjem til de okkuperte områdene etter noen år, giftet seg hjemme i Palestina, stiftet familier og oppdro sine barn i de byene hvor de selv vokste opp. De fikk aldri tilbake sine palestinske statsborgerskap og var nødt til å reise inn på turistvisum som måtte fornyes hver tredje måned. Mange palestinere bosatt på Vestbredden har også giftet seg med palestinere som er født i utlandet, 
men som har flyttet til Palestina i ung alder. Disse får heller ikke statsborgerskap og må også oppholde seg i landet på turistvisum. Siden i fjor sommer har israelske myndigheter nektet å fornye slike turistvisum, og palestinere som i flere år har reist til Jordan og tilbake hver tredje måned, blir nå stanset på grensen. Resultatet er at tusenvis av palestinere blir atskilt fra sine barn og ektefeller som fortsatt bor på Vestbredden, og familier tvinges til å forlate området for godt, eller å leve atskilt.

\section{De ressurssterke flykter}

Isoleringen av Betlehem, ekskluderingen fra det israelske arbeidsmarkedet, byggingen av muren og Israels nye grensepolitikk er maktmidler som sjeldent skaper dramatiske nyhetsbilder, men den samlede effekten av disse maktmidlene er brutalt klar: å gjøre tilværelsen såpass vanskelig, økonomisk og sosialt, at velutdannede, ressurssterke palestinere som har muligheten til å forlate landet, velger å gjøre det.

Mange mistenker at disse virkemidlene er del av en strukturell kampanje for å drive kristne palestinere ut av landet først. Fra israelsk hold fremstilles gjerne konflikten med palestinerne som en konflikt mellom jøder og muslimer. Det har også gjort det lett å sikre bred støtte fra kristne miljøer i usA og Europa. I et slikt bilde utgjør de kristne palestinerne et svært forstyrrende element. De kan ikke demoniseres som muslimske ekstremister, og de representerer en potensiell utfordring for det nære forholdet mellom Israel og kristne miljøer i Vesten. Mange kristne palestinere finner det derfor naturlig å anta at israelske myndigheter ønsker at de skal forsvinne først. Slike mistanker kan høres konspiratoriske ut, men de lokale realitetene er klare nok. Den økonomiske utarmingen av Betlehem bidrar til økt utvandring, og på grunn av deres klassemessige trekk er det spesielt de kristne som forlater området. De er ofte godt utdannede og har gode utenlandske kontakter, og de fleste av dem har gått på kristne privatskoler drevet av ulike kirker i Betlehem. På disse skolene har de blitt gjort kjent med de europeiske språk og kulturelle univers som har vært knyttet til de ulike kirkene. På katolske skoler har man lært fransk eller italiensk og blitt kjent med disse landenes kulturhistorier, på lutherske skoler har man lært å kjenne tysk språk og kultur og på ortodokse skoler har fokuset vært på gresk språk og kultur.

Mange har siden reist til Europa eller USA for å studere, ofte ved hjelp av stipender og gode kontakter fra de ulike kirkene. I tillegg har mange gode barndomsminner knyttet til ferier i utlandet og til en hverdag preget av langt større frihet og sikkerhet enn det de finner på Vestbredden i dag. Slike erfaringer har gitt mange en sterk kulturell orientering mot Vesten, i tillegg til forventninger om å kunne leve et trygt og godt middelklasseliv, med god økonomi og spennende karrierer, et rikt kulturtilbud, frihet til å reise hvor man vil og ikke minst gode fremtidsutsikter for sine barn. Dersom de ikke kan oppnå dette på Vestbredden, vil de oppsøke det $\mathrm{i}$ andre deler av verden. De som tar dette skrittet er både enslige unge menn og gifte par med eller uten barn, men de er ofte blant dem som er høyt utdannet, og som har omfattende familienettverk i utlandet.

\section{Et regionalt problem}

Denne utvandringen er for så vidt ikke unik for de palestinske områdene. Også fra 
andre land i regionen foregår det en omfattende utvandring til Vesten. Også i land som Syria, Libanon og Jordan har de kristne, som del av en velutdannet middelklasse med internasjonale kontakter, forlatt regionen oftere enn andre grupperinger. Også her har mange reist ut på grunn av mangel på økonomiske muligheter og et generelt fravær av politisk frihet og stabilitet. Dette er problemer som preger hele regionen, men som i de palestinske områdene er spesielt akutte etter nesten førti år under israelsk okkupasjon.

De strukturelle sidene ved denne okkupasjonen berøver folk for bevegelsesfrihet, underminerer økonomisk verdiskapning og kulturell aktivitet, fratar folk retten til egen jord og hindrer dem i å stifte familie og leve sammen med den man vil. Gitt deres generelle profil som folk av middelklassebakgrunn med internasjonale kontakter, så kan dette langt på vei forklare hvorfor så mange kristne palestinere velger å emigrere.

\section{"Den siste mohikaner"}

Den kristne utvandringen har også en svært selvforsterkende effekt. For det første har man en lang historie for utvandring, og mange har omfattende familienettverk spredt utover Nord- og Sør-Amerika. Emigrasjon har blitt en lokal tradisjon i Betlehemsområdet, og det å reise ut oppleves langt fra utrygt når man kan bli mottatt av familie og venner i andre deler av verden. Dermed representerer utvandring heller ikke et dramatisk brudd med ens lokal røtter, men en gjenoppretting av familiebånd i andre deler av verden. Utvandringen er også selvforsterkende i den forstand at den bidrar til et økende "minoritetskompleks" og opplevelse av tallmessig sårbarhet blant de som er igjen. Kristne palestinere spøker ofte med at man føler seg som "de siste mohikanere", men bak dette ligger

\section{En omfattende utvandring finner sted blant både kristne og muslimske palestinere som følge av okkupasjonen.

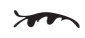

opplevelsen av at ens egne nettverk smuldrer bort gjennom utvandring, og at man selv utgjør en stadig mindre del av befolkningen. Siden I9I4 har andelen kristne sunket fra rundt I2 til I,5 prosent i de okkuperte områdene. Selv om de stort sett har et godt forhold til sine muslimske naboer, og selv om de selv har hatt en langt større samfunnsmessig innflytelse i området enn deres antall skulle tilsi, så skaper dette en frykt for en kulturell islamisering, og det oppleves som svært viktig å opprettholde visse "kristne" særtrekk ovenfor muslimene. De siste IO-I5 årene har man også fått en sterkere vektlegging av religiøse skillelinjer, og mange uttrykker bekymring over økende tendenser til sekterisk tenkning blant både kristne og muslimer. Det fryktes at man på sikt kan få en politisk og kulturell islamisering av samfunnet som gir de kristne stadig mindre sosialt handlingsrom, og at dette $\mathrm{i}$ fremtiden kan bidra til ytterligere utvandring. De som reiser ut i dag drar til i hovedsak til Europa, usA og Canada, på jakt etter utdanning, arbeid og en meningsfull fremtid. De reiser til land hvor de allerede har et nettverk av familie og venner, og hvor de har en mulighet til å slippe inn. De er innstilt på å lære nye språk om nød- 
vendig, og ellers ta de mulighetene som dukker opp, og som kan hjelpe dem å bygge nye liv utenfor Palestina.

\section{Intern kamp mot utvandring}

Samtidig er det mange som blir værende på Vestbredden av eget valg, og som ønsker å ta opp kampen mot utvandringen og å gjøre noe med dagens situasjon i Betlehem. De lokale kirkene har siden 2002 gjennomført en rekke tiltak, spesielt for å holde på unge familier i Betlehemsområdet. Kirkene prøver blant annet å skape nye arbeidsplasser for folk. Kirkene er langt på vei de viktigste arbeidsgiverne blant kristne palestinere, og omkring en av tre kristne arbeidstakere jobber for kirkene, kristne privatskoler, sykehjem eller andre organisasjoner tilknyttet kirkene i området. I tillegg har det blitt bygget store boligkomplekser i regi av de ulike kirkene, for å kunne tilby billige leiligheter til unge uetablerte familier som trenger egne hjem. Mange lokale organisasjoner jobber for å skape stolthet blant lokale kristne knyttet til deres arv og historie i området og bevissthet omkring utvandring som en trussel mot denne arven. Samtidig anses det viktig å spre informasjon til verden utenfor om situasjonen i Betlehem og Palestina generelt.

Dette vektlegges blant annet av Open Bethlehem, ${ }^{15}$ en lokal NGo etablert i 2005 , som har et todelt mål om å promotere Betlehem som turistmål og å spre informasjon om situasjonen $\mathrm{i}$ de palestinske områdene med Betlehem som utgangspunkt. Ved å fokusere på Betlehems plass i kristen lære og historie vender de seg spesielt til kristne i Europa og USA, og de vektlegger viktigheten av å ivareta en kristen tilstedeværelse i Betlehemsom- rådet. Gjennom denne virksomheten fremhever de sin egen identitet som både kristne og palestinere med en sterk forankring i arabisk kultur, samtidig som man konfronterer kristne grupperinger $i$ Vesten som gjennom lengre tid har gitt ensidig støtte til Israel.

Det er stor enighet om at kampen mot utvandring må føres på flere fronter. Den økonomiske krisen i området må konfronteres lokalt. Man trenger flere arbeidsplasser og billige boliger. Men de store avgjørende endringene må skje på politisk plan. Man kan ikke få etablert en sterk turistindustri i Betlehem og en levedyktig palestinsk økonomi så lenge Vestbredden er under okkupasjon, og så lenge området er avskåret fra Jerusalem. Inntil disse problemene er håndtert, er det all grunn til å tro at den kristne utvandringen vil fortsette.

$$
\cdot f \cdot
$$

I Forfatteren har vært på feltarbeid i Betlehemsområdet $\mathrm{i}$ perioden juni til desember 2006.

2 Sabella, Bernhard, 2000 "Palestinian Christians: Challenges and hopes." www.al-bushra.org/holyland/sabella.htm

3 Soudah, Romell: "Christians of the Holy Land. Across the political and economical divide". Presentation of Survey Results for the Sabeel Conference 2006. http://www. sabeel.org/pdfs/Romell\%2022\%20Final.doc

Sabella, Bernhard, "The Emigration of Christian Arabs: Dimensions and Causes of the Phenomenon" s. I27-I54. «Christian Communities in the Arab Middle East. The Challenge of the Future». Ed. Pacini, Andrea. I998. Oxford University Press. Clarendon Street, Oxford, UK.

5 Karpat, Kemal H, "The Ottoman Emigration to America", I860-I9I4. International Journal of Middle Eastern Studies, Vol I7, No.2 (May I985) s. I75-209

6 Tsimhoni, Daphne 200I "Israel and the Territories - Disappearance. Disappearing Christians of the Middle East". Middle East Quarterly Winter 200I, Vol 8, nr. I.

7 Gonzales, Nancie, “Dollars, Dove and Eagle. One Hundred Years of Palestinian Migration to Honduras." Ann Arbor: The University of Michigan Press. 1992

8 Intervjuer med borgermestrene i Bethlehem, Beit Jala og Beit Sahour. 
9 Farsoun, Samih K \& Zacharia, Christina E: «Palestine and the Palestinians». Westview Press. Boulder, Colorado. I997.

Io Soudah, Romell: "Christians of the Holy Land. Across the political and economical divide." Presentation of Survey Results for the Sabeel Conference 2006. http://www. sabeel.org/pdfs/Romell\%2022\%2oFinal.doc

II "O Little Town of Bethlehem: What is its Future?", Applied Research Institute-Jerusalem (ARIJ) Bethlehem, Palestine. 2005 .

I2 "The Cost of Conflict: The Changing face of Bethlehem". Report 20. Dec 2004, UN - Office for the Coordination of Humanitarian Affairs (ocHA), Jerusalem

I3 Intervju med Dr. Jad Isaac, forskningsleder ved Applied Research Center in Jerusalem (ARIJ).

I4 Pacini, Andrea, "Introduction" s. I-24 og "Sociopolitical and Community Dynamics of Arab Christians in Jordan, Israel and the Autonomous Palestinian Territories" s. 259-286. «Christian Communities in the Arab Middle East. The Challenge of the Future». Ed. Pacini, Andrea. I998. Oxford University Press. Clarendon Street, Oxford, UK.

I5 http://www.openbethlehem.org/ 